\title{
A multiplex PCR assay for the simultaneous detection of Taenia hydatigena, T. multiceps, T. pisiformis, and Dipylidium caninum infections
}

Guo-Qiang Zhu' ${ }^{1 \dagger}$, Li Li ${ }^{1 \dagger}$, John Asekhaen Ohiolei', Yan-Tao Wu', Wen-Hui Li', Nian-Zhang Zhang ${ }^{1}$, Bao-Quan Fu', Hong-Bin Yan $^{1 *}$ and Wan-Zhong Jia ${ }^{1,2^{*}}$

\begin{abstract}
Background: Taenia hydatigena, T. multiceps, T. pisiformis, and Dipylidium caninum are four common large and medium-sized tapeworms parasitizing the small intestine of dogs and other canids. These parasites cause serious impact on the health and development of livestock. However, there are, so far, no commercially available molecular diagnostic kits capable of simultaneously detecting all four parasites in dogs. The aim of the study was therefore to develop a multiplex PCR assay that will accurately detect all four cestode infections in one reaction.

Methods: Specific primers for a multiplex PCR were designed based on corresponding mitochondrial genome sequences, and its detection limit was assessed by serial dilutions of the genomic DNAs of tapeworms examined. Furthermore, field samples of dog feces were tested using the developed assay.

Results: A multiplex polymerase chain reaction (PCR) assay was developed based on mitochondrial DNA (mtDNA) that accurately and simultaneously identify four cestode species in one reaction using specific fragment sizes of 592, 385, 283, and $190 \mathrm{bp}$ for T. hydatigena, T. multiceps, T. pisiformis, and D. caninum, respectively. The lowest DNA concentration detected was $1 \mathrm{ng}$ for T. hydatigena, T. multiceps and T. pisiformis, and $0.1 \mathrm{ng}$ for D. caninum in a $25 \mu \mathrm{l}$ reaction system. This assay offers high potential for the rapid detection of these four tapeworms in host feces simultaneously.

Conclusions: This study provides an efficient tool for the simultaneous detection of T. hydatigena, T. multiceps, T. pisiformis, and D. caninum. The assay will be potentially useful in epidemiological studies, diagnosis, and treatment of these four cestodes infections during prevention and control program.
\end{abstract}

Keywords: Multiplex PCR, Canids, Tapeworms, Mitochondrial DNA

\section{Background}

Historically, cestodes are parasites that have caused serious damage to wild and domestic animals as well as human health since antiquity, resulting in economic losses by affecting food safety, livestock production, and serious public health consequences [1,2]. Some cestode infection such as those caused by Echinococcus and Taenia are

\footnotetext{
*Correspondence: yanhongbin@caas.cn; jiawanzhong@caas.cn

${ }^{\dagger}$ Guo-Qiang Zhu and Li Li contributed equally to this work.

${ }^{1}$ State Key Laboratory of Veterinary Etiological Biology/ Key Laboratory of Veterinary Parasitology of Gansu Province/ Lanzhou Veterinary Research Institute, CAAS, Lanzhou 730046, Gansu Province, People's Republic of China Full list of author information is available at the end of the article
}

widespread and of significant public health concerns with challenges of prevention and control [3-8]. For example, a recent survey report from Tanzania has shown that the infection rates of cysticercosis in goats and sheep could reach as high as 61.1 and $42.2 \%$, respectively [6]; the prevalence rates of alveolar echinococcosis (AE) cases of childhood as high as 12.1 (Tehetu) and 11.8\% (Moba) in Dari County, China [9].

Taenia hydatigena, T. multiceps, T. pisiformis, and D. caninum are four common parasites that parasitize the small intestine of dogs with their larvae causing cysticercosis tenuicollis, coenurosis, cysticercosis pisiformis and

(c) The Author(s). 2019 Open Access This article is distributed under the terms of the Creative Commons Attribution 4.0 International License (http://creativecommons.org/licenses/by/4.0/), which permits unrestricted use, distribution, and reproduction in any medium, provided you give appropriate credit to the original author(s) and the source, provide a link to the Creative Commons license, and indicate if changes were made. The Creative Commons Public Domain Dedication waiver (http://creativecommons.org/publicdomain/zero/1.0/) applies to the data made available in this article, unless otherwise stated. 
dipylidiasis in intermediate hosts, respectively. Cats and foxes also can act as definitive hosts of D. caninum [10]. In some cases, these parasites have resulted in serious medical concerns in different parts of the world due to their zoonotic potential in humans [10, 15-18], while seriously impacting the health and development of animals/ livestock [11-14]. For instance, a recent study indicated that $9.1 \%$ of $D$. caninum infection rates occurred in dogs in Europe [19] and 6.3\% of red foxes were found to be infected with T. multiceps [20]; the overall infection rates for T. hydatigena were $61.1 \%$ in goats and $42.2 \%$ in sheep in a Malambo (a village) slaughter slab in Tanzania [6]; and $8.3 \% \mathrm{~T}$. hydatigena positive dogs and foxes in Australia [21]. Therefore, specific and effective detection methods are highly crucial for the identification, prevention and control of these parasitic infections [22].

So far, there are no commercially available molecular diagnostic kits for the simultaneous detection of multiple infections by all four cestodes in a host. Although enzyme-linked immunosorbent assay (ELISA) is being used for the diagnosis of $T$. hydatigena, T. multiceps, and $T$. pisiformis infections, challenges of misdiagnosis as a result of false-positive and false-negative remains a major issue [23-25]. The multiplex PCR assay permits the simultaneous and accurate detection of multiple parasites [26, 27], and the mitochondrial $(m t)$ DNAs are one of the important multiplex PCR target molecules owing to their particular characteristics of nucleotide variation and high polymorphism [28, 29]. Consequently, for the first time, we developed a multiplex PCR assay to detect and discriminate $T$. hydatigena, T. multiceps, $T$. pisiformis and $D$. caninum infections, which will be important for the epidemiology, diagnoses, and control of cestode infections.

\section{Methods}

\section{Origin of specimens and DNA extraction}

Samples of adult parasites and dog feces were obtained from the Animal Center of State Key Laboratory of Veterinary Etiological Biology, Lanzhou Veterinary Research Institute, CAAS, People's Republic of China, and stored at $-80^{\circ} \mathrm{C}$ until DNA extraction. Genomic DNAs were extracted from adult parasites using DNeasy Blood and Tissue Kit (QIAGEN, Hilden, Germany) and dog feces (180-220 mg) using QIAamp ${ }^{\circ}$ DNA Stool Mini Kit (QIAGEN, Hilden, Germany), DNA elution was achieved with $20 \mu \mathrm{l}$ of elution buffer. DNA concentration and purity were determined using a spectrophotometer (TECAN, Tecan' Infinite 200 PRO NanoQuant) and stored at $-20^{\circ} \mathrm{C}$ until use [28].

\section{Primer design}

Based on the alignment of the mtDNAs of $T$. hydatigena, T. multiceps, T. pisiformis and D. caninum with online tool ClustalW (http://www.simgene.com/ClustalW), multiplex PCR primers were designed by targeting conserved sequences flanking variable regions with the help of Oligo primer software. Each set of primer pairs were checked for specificity using the NCBI database online tool Nucleotide BLAST (https://blast.ncbi. nlm.nih.gov/Blast.cgi). Details of primer pairs are presented in Table 1.

\section{Multiplex PCR assay}

Multiplex PCR reaction parameters were optimized and the reaction was carried out in a final reaction volume of $25 \mu \mathrm{l}$ containing $0.1 \mu \mathrm{g}$ genomic DNA, $4 \mu \mathrm{l}$ optimal primers with each primer $(10 \mu \mathrm{M})$ contributing $0.5 \mu \mathrm{l}$ (Th-F/R for T. hydatigena, Tm-F/R for T. multiceps, TpF/R for T. pisiformis and Dc-F/R for D. caninum), and $12.5 \mu \mathrm{l}$ Premix $\operatorname{Taq}^{\text {Tu }}(5 \mathrm{U} / \mathrm{ml})$ (Takara Bio, Japan). Fragments were amplified using the following optimized thermal cycling conditions: $95^{\circ} \mathrm{C} / 5 \mathrm{~min}$ for initial denaturation; 30 cycles of $94^{\circ} \mathrm{C} / 30 \mathrm{~s}$ for denaturation, $55^{\circ} \mathrm{C} / 30$ s for annealing, $72{ }^{\circ} \mathrm{C} / 40$ s for extension; $72{ }^{\circ} \mathrm{C} /$ $10 \mathrm{~min}$ for final extension; and amplification products were stored at $4{ }^{\circ} \mathrm{C}$ until they were visualized.

\section{Identification of PCR products}

PCR products $(8 \mu \mathrm{l})$ were visualized by electrophoresis in $2.0 \%(\mathrm{w} / \mathrm{v})$ agarose gels that were pre-stained with ethidium bromide (EB) and viewed under UV light (BIORAD, Molecular Imager ${ }^{\circ}$ chemiDoc $^{\text {Th }}$ XRS + with image $\mathrm{lab}^{\mathrm{Tw}}$ software). The electrophoretic buffer solution was $1 \times$ TAE buffer [30].

\section{Specificity and limit of the assay}

The specificity of the multiplex PCR was verified using genomic DNAs of other common tapeworms (E. canadendsis (G7), E. granulosus, E. multilocularis and E. shiquicus) inhabiting the small intestine of canids. Furthermore, the lowest detected DNA was verified using serial dilutions of genomic DNA of each parasite in nuclease-free water, and the final DNA concentration for each parasite in a $25 \mu \mathrm{l}$ reaction system was $10,1.0,1.0 \times$ $10^{-1}, 1.0 \times 10^{-2}, 1.0 \times 10^{-3}, 1.0 \times 10^{-4} \mathrm{ng}$, respectively.

\section{Field application of the multiplex PCR}

The usefulness of the newly developed assay was verified using genomic DNAs from dog feces as templates. The multiplex PCR assay was carried out in a final reaction mixture of $25 \mu \mathrm{l}$, containing $2 \mu \mathrm{l}$ templates, $4 \mu \mathrm{l}$ optimal primers with $0.5 \mu \mathrm{l}$ from each forward and reverse primer (Th-F/R for T. hydatigena, Tm-F/R for T. multiceps, Tp-F/R for T. pisiformis and Dc-F/R for D. caninum), and $12.5 \mu \mathrm{l}$ Premix $\operatorname{Taq}^{\text {Ti }}$ (Takara Bio, Japan), followed by thermal cycling conditions and visualization process mentioned above. 
Table 1 Forward and reverse primers used in the multiplex PCR for Taenia hydatigena, T. multiceps, T. pisiformis, and Dipylidium

\begin{tabular}{|c|c|c|c|c|}
\hline Species & Primer names and sequences $5^{\prime}-3^{\prime}$ & $\begin{array}{l}\text { Expected amplicon } \\
\text { size (bp) }\end{array}$ & $\begin{array}{l}\text { The location of primers in the } \\
\text { mtDNA }\end{array}$ & $\begin{array}{l}\text { Accession no. of } m \text { tDNAs in NCBI } \\
\text { GenBank }\end{array}$ \\
\hline \multirow[t]{2}{*}{$\begin{array}{l}T . \\
\text { hydatigena }\end{array}$} & $\begin{array}{l}\text { Th-F: AGTTCCATATTATTTACAGTTTGTT } \\
\text { ATTAC }\end{array}$ & 592 & 12,446 & NC_012896 \\
\hline & Th-R: TAACATAATACTTGAAGACACCCCCA & & 13,038 & \\
\hline \multirow[t]{2}{*}{ T. multiceps } & Tm-F: GTTGTTGATGTGGCTTAAGTITTGTGT & 385 & 10,902 & NC_012894 \\
\hline & $\begin{array}{l}\text { Tm-R: TCTATAAAATAAACACATACACAACA } \\
\text { ATCCT }\end{array}$ & & 11,287 & \\
\hline \multirow[t]{2}{*}{ T. pisiformis } & Tp-F: TGTGGGAAGGTTAAGGTGAATCAT & 283 & 200 & NC_013844 \\
\hline & $\begin{array}{l}\text { Tp-R: GTTAACATCAATATCTTCTAGCTCTG } \\
\text { ACACT }\end{array}$ & & 483 & \\
\hline \multirow[t]{2}{*}{ D. caninum } & Dc-F: CTATTGATTGCGTTTATTGTTTTGTGT & 190 & 8594 & MG587892 \\
\hline & $\begin{array}{l}\text { Dc-R: GAAAAGAAATCAAATACAGTTAAACG } \\
\text { GT }\end{array}$ & & 8784 & \\
\hline
\end{tabular}

Annotation: $F$, forward primer; $R$, reverse primer; $b p$, base pairs

\section{Results}

\section{Specificity}

According to the location of designed primers, the expected size of multiplex PCR amplicons for each species was $592 \mathrm{bp}$ (T. hydatigena), $385 \mathrm{bp}$ (T. multiceps), $283 \mathrm{bp}$ (T. pisiformis) and $190 \mathrm{bp}$ (D. caninum), respectively. As expected, all PCR products were of exact band sizes, and when DNA templates from other tapeworms were involved in the multiplex PCR assay, no PCR products were produced (Fig. 1).

The multiplex PCR products of mixed templates of the four parasites are shown in Fig. 2. The products containing two DNA bands (592 and 385 bp, 592 and 283 bp, 592 and $190 \mathrm{bp}, 385$ and $283 \mathrm{bp}, 385$ and $190 \mathrm{bp}, 283$ and 190 bp) were amplified with mixed DNA templates of $T$. hydatigena and T. multiceps, T. hydatigena and T. pisiformis, T. hydatigena and D. caninum, T. multiceps and T. pisiformis, T. multiceps and D. caninum, T. pisiformis and D. caninum, respectively. Three DNA bands (592, 385 and $283 \mathrm{bp} ; 592,385$ and $190 \mathrm{bp}$; 385, 283 and $190 \mathrm{bp)}$ were amplified with mixed DNA templates of T. hydatigena, $T$. multiceps and T. pisiformis; T. hydatigena, T. multiceps and D. caninum; T. multiceps, T. pisiformis and D. caninum. Four DNA bands (592, 385, 283 and $190 \mathrm{bp}$ ) were amplified with mixed DNA templates of $T$. hydatigena, $T$. multiceps, T. pisiformis and D. caninum (Fig. 2).

\section{Detection minimum limit}

The minimum detection limit was determined by different DNA gradients with $10,1.0,1.0 \times 10^{-1}, 1.0 \times 10^{-2}$, $1.0 \times 10^{-3}, 1.0 \times 10^{-4} \mathrm{ng}$, respectively. The results indicated that the lowest limit for the DNA detection was 1 ng for T. hydatigena, T. multiceps or T. pisiformis and $0.1 \mathrm{ng}$ for D. caninum, respectively (Fig. 3).

\section{Evaluation of field samples}

In the field application of this multiplex PCR assay, a total of $25 \mathrm{dog}$ feces were tested. One sample tested positive with a fragment size of about $385 \mathrm{bp}$ identified as T. multiceps infection (Fig. 4).

\section{Discussion}

Until now, due to the lack of accurate and simultaneous detection methods in a single reaction for these four

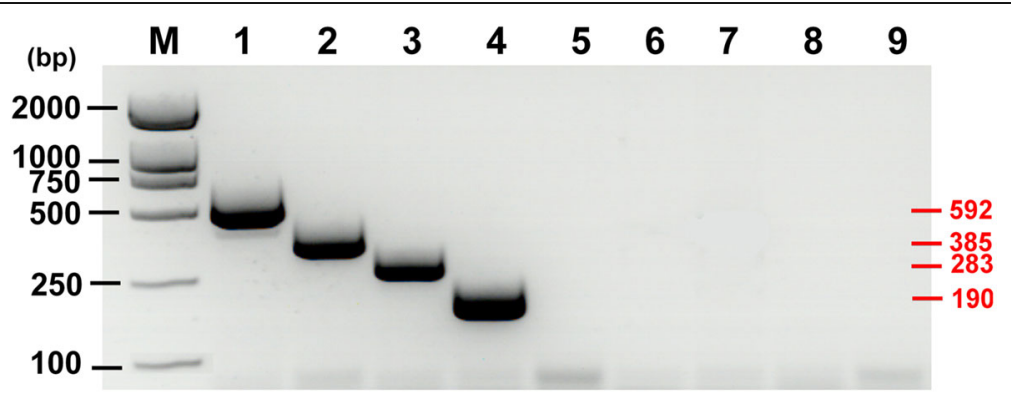

Fig. 1 Development of the multiplex PCR specific assay for four pathogenic dogs parasites. Lane 1-8: The products of PCR amplification using the genomes of Taenia hydatigena, T. multiceps, T. pisiformis, Dipylidium caninum, Echinococcus canadensis, E. granulosus, E. multilocularis and E. shiquicus as templates, respectively; Lane 9: negative control; Lane M: 2000 bp DNA standard marker 


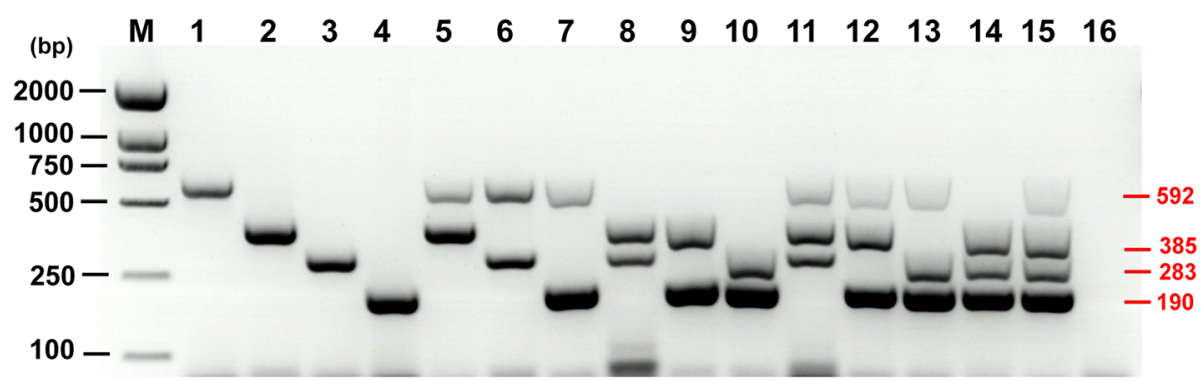

Fig. 2 The specificity analysis of the 4 sets of primers using various combined target templates. Lanes 1-4: PCR amplification result of Taenia hydatigena, T. multiceps, T. pisiformis and Dipylidium caninum as single template, respectively; Lanes 5-10: PCR amplification result of Th + Tm, $T h+T p, T h+D c, T m+T p, T m+D c$ and Tp + Dc as dual templates, respectively; Lanes 11-14: PCR amplification result of Th + Tm + Tp, Th + Tm + $D c, T h+T p+D c$ and $T m+T p+D c$ as triple templates, respectively; Lane 15: PCR amplification result of Th $+T m+T p+D c$ as quadruple templates; Lane 16: negative control; Lane M: 2000 bp DNA standard marker

cestode parasites (T. hydatigena, T. multiceps, T. pisiformis and D. caninum), it is noteworthy that traditional detection and diagnosis mostly relies on post-mortem examination by experts, which is laborious and timeconsuming $[13,31]$ coupled with the challenge of misdiagnosis $[10,32]$. Although the diagnosis can also be achieved with immunodiagnostic assays such as antigen enzymelinked immunosorbent assay (Ag-ELISA), cross-reaction with other Taenia spp. sharing similar antigenic properties has also been a challenge [23]. In this study, we developed a multiplex assay which is sensitive to discriminate and diagnose four cestode parasites simultaneously in a single reaction compare to the conventional PCR method (requiring only a pair of primers in a reaction system). The specificity analysis showed that no cross-reactivity was observed with other tapeworms inhabiting the small intestine as well as with each other, and the minimum detected DNA ranged from 0.1 to $1 \mathrm{ng}$, low enough to produce results in case of low DNA yield.

Two obligate mammalian hosts are essential for the transmission of some cestode parasites including $T$. hydatigena, T. multiceps and T. pisiformis, which is dependent on prey-predator associations of intermediate hosts (including humans) and definitive hosts [33].
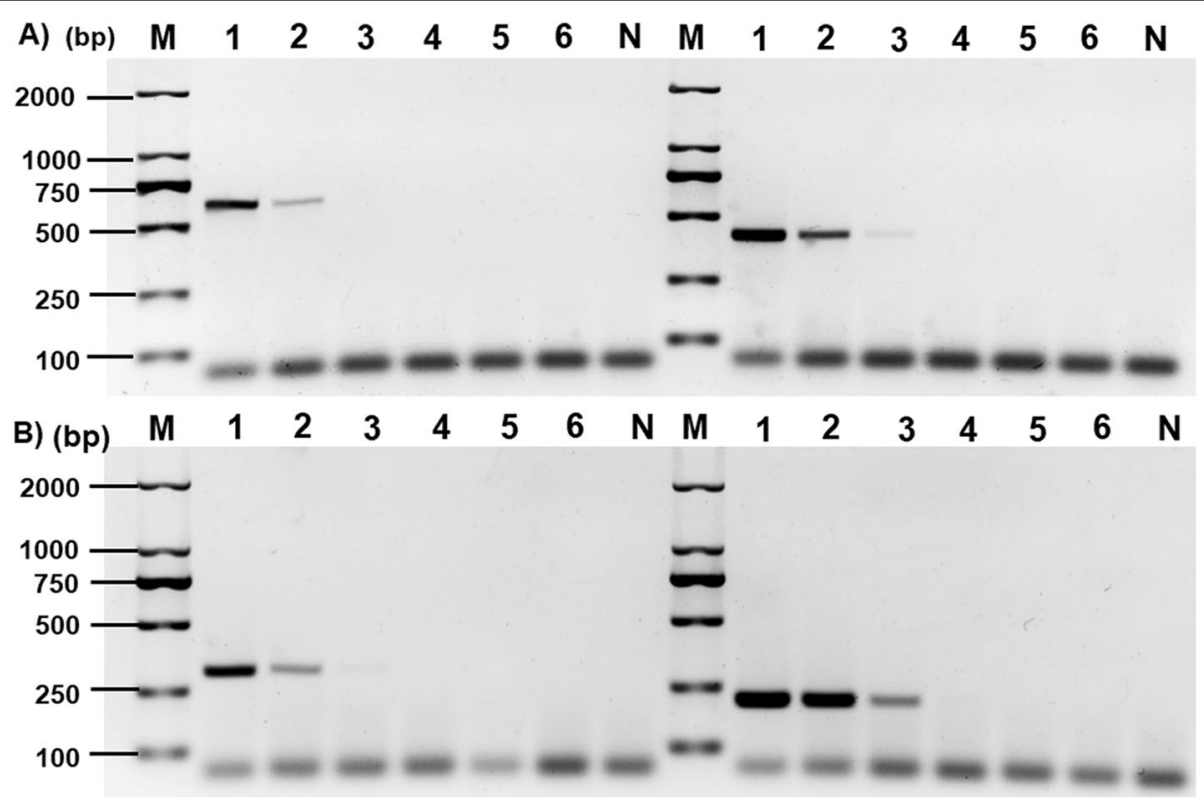

Fig. 3 The multiplex PCR sensitivity assay for four pathogenic dogs parasites. Lanes 1-6: the concentrations of serial dilutions differ templets are $10,1.0,1.0 \times 10^{-1}, 1.0 \times 10^{-2}, 1.0 \times 10^{-3}, 1.0 \times 10^{-4} \mathrm{ng}$, respectively; Lane M: $2000 \mathrm{bp}$ DNA standard marker; Lane N is negative control. a): This picture showing the amplicons of 592 and 385 bp produced in a $25 \mu$ PCR system with differ DNA concentrations of Taenia hydatigena (left) and T. multiceps (right) templates, respectively; b): This Picture showing the amplicons of 283 and 190 bp produced in a $25 \mu \mathrm{l}$ PCR system with differ DAN concentrations of T. pisiformis (left) and Dipylidium caninum (right) templates, respectively 


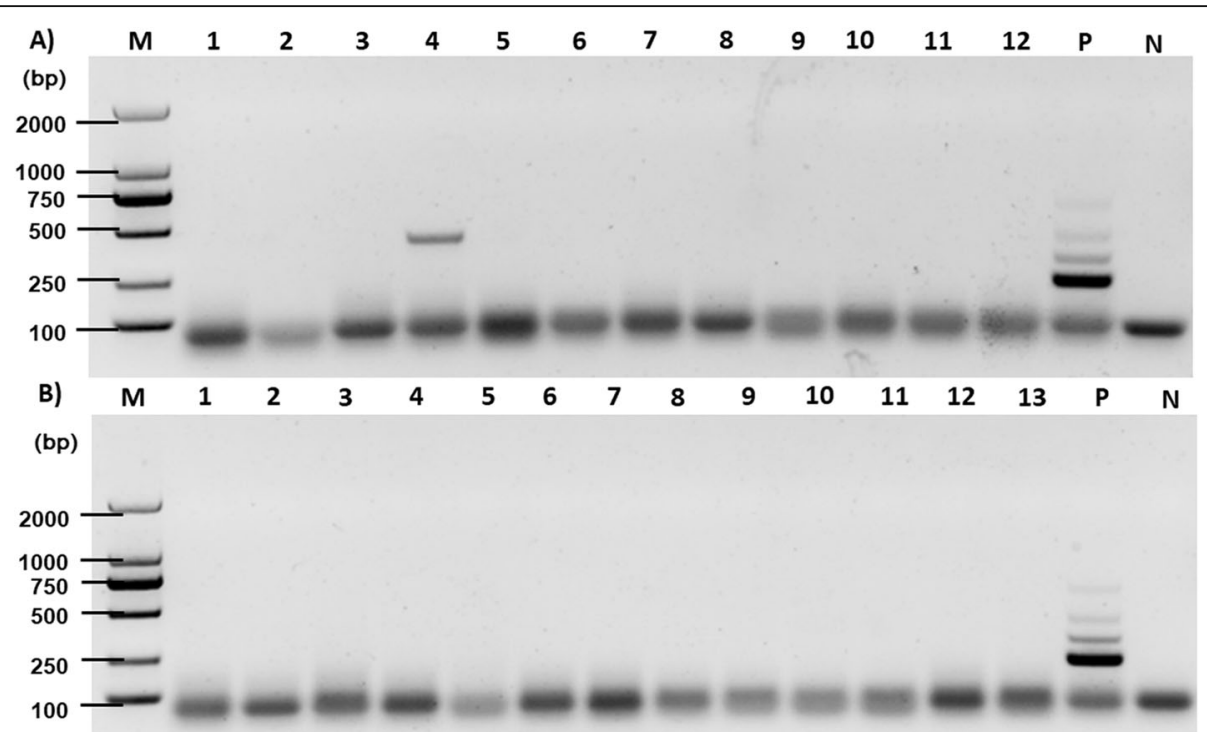

Fig. 4 The PCR results of DNA sample from dog feces. $\mathbf{a}$ and $\mathbf{b}$ represent the results of two sets of PCR experiments for dog feces. Lane M: 2000 bp DNA standard marker; Lanes 1-12: DNA sample of dog feces; Lane P: Positive control with genomic DNA from adult parasites of representative tapeworms from dogs; Lane $\mathrm{N}$ : negative control

Infections by these parasites often lead to serious damage in intermediate hosts than in definitive hosts where infections are subclinical [34-36]. Therefore, effective control measures are often targeted at the definitive hosts that are capable of transmitting and maintaining the infection within an environment. Similarly, this is also the case for Echinococcus spp. infections which are commonly observed in dogs and other canids in China $[37,38]$. However, the recent establishment of a multiplex PCR method for the detection of multiple infections with E. granulosus sensu stricto, E. multilocularis and E. shiquicus [28], has provided a rapid, sensitive, and costeffective method in discriminating these infections. Also, the establishment of a detection method that is accurate and inexpensive for the discrimination of T. hydatigena, T. multiceps, T. pisiformis and D. caninum infections in definitive hosts is a step further in achieving prevention and control.

Mitochondrial genes are amongst the most popular molecular markers that have been widely used in molecular ecology, population genetics, and diagnoses of parasitic organisms $[26,39]$. Therefore, we explored the $m t$ genes as molecular markers to develop a multiplex PCR system for the synchronous detection of the four tapeworm infections. However, some challenges were confronted with sample collection and fecal DNA extraction. For example, poor DNA yield, which could be due to a number of inhibitors and the complex presence of other organisms in the feces, the of feces (fresh or old) and the uneven distribution of parasite eggs.

Nonetheless, with the continuous advancement in biomedical/life sciences, alternative molecular markers such as microRNAs (miRNAs) [40], microsatellite DNAs [41] and improved DNA extraction methods may provide further opportunity for the development of more detection and diagnostic methods for epidemiological investigations.

We admit that the current study had a limitation of appropriately assessing the sensitivity of this assay. However, we recommended that, prior to DNA extraction, conventional flotation/sedimentation technique should be used to concentrate cestode eggs from feces in order to increase the sensitivity. Also, regarding the presence of other cestodes of canids such as T. ovis, T crassiceps, $T$. serialis and T. gaigeri which were not assessed in this study, application of this test will be limited to areas where the four tapeworms $T$. hydatigena, T. multiceps, T. pisiformis and $D$. caninum are prevalent. Nevertheless, the design principles or skills of multiplex PCR primers and methods in this study and others can be followed or adopted in other areas where other taenids co-exist in canids. Moreover, standard parasitological methods should be used simultaneously to differentiate the worms.

\section{Conclusion}

The multiplex PCR assay is an efficient tool for the detection and simultaneous diagnosis of T. hydatigena, T. multiceps, T. pisiformis, and D. caninum tapeworms from DNA sample, the lowest limit of detectable DNA was $1 \mathrm{ng}$ for T. hydatigena, T. multiceps, and T. pisiformis, and 0.1 ng for $D$. caninum, respectively. Consequently, this assay will be potentially useful in epidemiological studies, diagnosis, and treatment of taeniasis or cestode infections during prevention and control program. 


\section{Abbreviations}

ELISA: Enzyme-linked immunosorbent assay; $m$ t: mitochondrial; bp: base pair; PCR: Polymerase chain reaction

\section{Acknowledgments}

We are grateful to Gang Yao and Wen-Jun Tian for their assistance sample collection.

\section{Author's contributions}

All authors contributed to the samples collection. WZJ, HBY, LL, and BQF designed the study. GQZ, JAO, YTW, WHL, and NZZ assisted to complete the experiment. GQZ undertook data analysis and wrote the manuscript. WZJ and JAO provided comments and modified the manuscript. All authors read and approved the final version of the manuscript.

\section{Funding}

This study received funding support from the National Key Research and Development Program of China (2017YFD0501301), National Key Basic Research Program (973 Program) of China (2015CB150300), the Gansu Provincial Key Science and Technology Projects (1203NKDA039), Central Public-interest Scientific Institution Basal Research Fund (1610312017001, 1610312016012), and the Science Fund for Creative Research Groups of Gansu Province (1210RJIA006). The funding bodies had no role in the design of the study, sample collection, analysis and interpretation of data and in writing the manuscript.

\section{Availability of data and materials}

The datasets used and/or analyzed during the current study are available from the corresponding author on reasonable request.

\section{Ethics approval and consent to participate}

Dogs used in this study were handled in strict accordance with good animal practice according to the animal ethics procedures and guidelines for animal husbandry and wildlife protection. The study was approved by the Animal Ethics Committee of Lanzhou Veterinary Research Institute, Chinese Academy of Agricultural Sciences (No. LVRIAEC2012-007).

\section{Consent for publication}

Not applicable.

\section{Competing interests}

The authors declare that they have no competing interests.

\section{Author details}

'State Key Laboratory of Veterinary Etiological Biology/ Key Laboratory of Veterinary Parasitology of Gansu Province/ Lanzhou Veterinary Research Institute, CAAS, Lanzhou 730046, Gansu Province, People's Republic of China. ${ }^{2}$ Jiangsu Co-innovation Center for Prevention and Control of Important Animal Infectious Disease, Yangzhou, 225009 Jiangsu Province, People's Republic of China.

\section{Received: 18 January 2019 Accepted: 26 September 2019}

\section{Published online: 16 October 2019}

\section{References}

1. Hoberg EP. Taenia tapeworms: their biology, evolution and socioeconomic significance. Microbes Infect. 2002;4(8):859-66.

2. Borji $\mathrm{H}$, Azizzadeh $\mathrm{M}$, Kamelli $\mathrm{M}$. A retrospective study of abattoir condemnation due to parasitic infections: economic importance in Ahwaz, southwestern Iran. J Parasitol. 2012;98(5):954-7.

3. Khademvatan S, Majidiani H, Foroutan M, Hazrati Tappeh K, Aryamand S, Khalkhali HR. Echinococcus granulosus genotypes in Iran: a systematic review. J Helminthol. 2019:93(2):131-8.

4. Oksanen A, Siles-Lucas M, CKaramon J, Possenti A, Conraths FJ, Romig T, Wysocki P, Mannocci A, Mipatrini D, La Torre G, Boufana B, Casulli A. The geographical distribution and prevalence of Echinococcus multilocularis in animals in the European Union and adjacent countries: a systematic review and meta-analysis. Parasit Vectors. 2016; 9(1):519.

5. Openshaw Jl, Medina A, Felt SA, Li T, Huan Z, Rozelle S, Luby SP. Prevalence and risk factors for Taenia solium cysticercosis in school-aged children: a school based study in western Sichuan, People's Republic of China. PLoS Negl Trop Dis. 2018;12(5):e0006465.

6. Miran MB, Kasuku AA, Swai ES. Prevalence of echinococcosis and Taenia hydatigena cysticercosis in slaughtered small ruminants at the livestockwildlife interface areas of Ngorongoro. Tanzania Vet World. 2017;10(4):411-7.

7. Villeneuve A, Polley L, Jenkins E, Schurer J, Gilleard J, Kutz S, Conboy G, Benoit D, Seewald W, Gagńe F. Parasite prevalence in fecal samples from shelter dogs and cats across the Canadian provinces. Parasit Vectors. 2015;8:281.

8. Flisser A. Eliminating cystic echinococcosis in the 21st century. Lancet Infect Dis. 2018;18(7):703-4.

9. Han XM, Cai QG, Wang W, Wang H, Zhang Q, Wang YS. Childhood suffering: hyper endemic echinococcosis in Qinghai-Tibetan primary school students. China Infect Dis Poverty. 2018;7(1):71.

10. Jiang P, Zhang X, Liu RD, Wang ZQ, Cui J. A human case of zoonotic dog tapeworm, Dipylidium caninum (Eucestoda: Dilepidiidae), in China. Korean J Parasitol. 2017:55(1):61-4.

11. Scala A, Pipia AP, Dore F, Sanna G, Tamponi C, Marrosu R, Bandino E, Carmona C, Boufana B, Varcasia A. Epidemiological updates and economic losses due to Taenia hydatigena in sheep from Sardinia. Italy Parasitol Res. 2015:114(8):3137-43.

12. Hallal-Calleros C, Morales-Montor J, Orihuela-Trujillo A, Togno-Peirce C, Murcia-Mejia C, Bielli A, Hoffman KL, Flores-Perez Fl. Taenia pisiformis cysticercosis induces decreased prolificacy and increased progesterone levels in rabbits. Vet Parasitol. 2016;229:50-3.

13. Saini VK, Gupta S, Kasondra A, Rakesh RL, Latchumikanthan A. Diagnosis and therapeutic management of Dipylidium caninum in dogs: a case report. J Parasit Dis. 2016:40(4):1426-8.

14. Amer S, ElKhatam A, Fukuda Y, Bakr LI, Zidan S, Elsify A, Mohamed MA, Tada C, Nakai Y. Prevalence and identity of Taenia multiceps cysts "Coenurus cerebralis" in sheep in Egypt. Acta Trop. 2017;176:270-6.

15. Cabello RR, Ruiz AC, Feregrino RR, Romero LC, Feregrino RR, Zavala JT. Dipylidium caninum infection. BMJ Case Rep. 2011;2011.

16. Tsumura N, Koga H, Hidaka H, Mukai F, Ikenaga M, Otsu Y, Masunaga K, Nagai K, Yoneda Y, Fukuma T, Ishimoto K. Dipylidium caninum infection in an infant. Kansenshogaku Zasshi. 2007:81(4):456-8.

17. Benifla M, Barrelly R, Shelef I, El-On J, Cohen A, Cagnano E. Huge hemispheric intraparenchymal cyst caused by Taenia multiceps in a child. Case report J Neurosurg. 2007;107(Suppl 6):511-4.

18. El-On J, Shelef I, Cagnano E, Benifla M. Taenia multiceps: a rare human cestode infection in Israel. Vet Ital. 2008;44(4):621-31.

19. Beugnet F, Labuschagne M, Fourie J, Jacques G, Farkas R, Cozma V, Halos L, Hellmann K, Knaus M, Rehbein S. Occurrence of Dipylidium caninum in fleas from client-owned cats and dogs in Europe using a new PCR detection assay. Vet Parasitol. 2014;205(1-2):300-6.

20. Varcasia A, Tamponi C, Tosciri G, Pipia AP, Dore F, Schuster RK, Kandil OM, Manunta ML, Scala A. Is the red fox (Vulpes vulpes) a competent definitive host for Taenia multiceps? Parasit Vectors. 2015;8(1):491.

21. Jenkins DJ, Urwin NA, Williams TM, Mitchell KL, Lievaart JJ, Armua-Fernandez MT. Red foxes (Vulpes vulpes) and wild dogs (dingoes (Canis lupus dingo) and dingo/domestic dog hybrids), as sylvatic hosts for Australian Taenia hydatigena and Taenia ovis. Int J Parasitol Parasites Wildl. 2014;3(2):75-80

22. Kollataj W, Milczak A, Kollataj B, Karwat ID, Sygit M, Sygit K. Risk factors for the spread of parasitic zoonoses among dog owners and their families in rural areas. Ann Agric Environ Med. 2012;19(1):79-84.

23. Wang $Y$, Nie H, Gu X, Wang T, Huang X, Chen L, Lai W, Peng X, Yang G. An ELISA using recombinant TmHSP70 for the diagnosis of Taenia multiceps infections in goats. Vet Parasitol. 2015:212(3-4):469-72.

24. Chen L, Yang D, Gu X, Peng X, Yang G. Evaluation of a novel dot-ELISA assay utilizing a recombinant protein for the effective diagnosis of Taenia pisiformis larval infections. Vet Parasitol. 2014;204(3-4):214-20.

25. Kajugu PE, Hanna RE, Edgar HW, Forster FI, Malone FE, Brennan GP, Fairweather I. Specificity of a coproantigen ELISA test for fasciolosis: lack of cross-reactivity with Paramphistomum cervi and Taenia hydatigena. Vet Rec. 2012:171(20):502.

26. Jia WZ, Yan HB, Guo AJ, Zhu XQ, Wang YC, Shi WG, Chen HT, Zhan F, Zhang SH, Fu BQ, Littlewood DT, Cai XP. Complete mitochondrial genomes of Taenia multiceps $T$ hydatigena and T pisiformis: additional molecular markers for a tapeworm genus of human and animal health significance. BMC Genomics. 2010;11:447. 
27. Curole JP, Kocher TD. Mitogenomics: digging deeper with complete mitochondrial genomes. Trends Ecol Evol. 1999;14(10):394-8.

28. Liu CN, Lou ZZ, Li L, Yan HB, Blair D, Lei MT, Cai JZ, Fan YL, Li JQ, Fu BQ, Yang YR, DP MM, Jia WZ. Discrimination between E. granulosus sensu stricto, E. multilocularis and E. shiquicus Using a Multiplex PCR Assay. PLoS Negl Trop Dis. 2015;9(9):e0004084.

29. Henegariu O, Heerema NA, Dlouhy SR, Vance GH, Vogt PH. Multiplex PCR: critical parameters and step-by-step protocol. Biotechniques. 1997;23(3):504-11.

30. Zimm BH, Levene SD. Problems and prospects in the theory of gel electrophoresis of DNA. Q Rev Biophys. 1992;25(2):171-204.

31. Braae UC, Kabululu M, Normark ME, Nejsum P, Ngowi HA, Johansen MV. Taenia hydatigena cysticercosis in slaughtered pigs, goats, and sheep in Tanzania. Trop Anim Health Prod. 2015;47(8):1523-30.

32. Samkari A, Kiska DL, Riddell SW, Wilson K, Weiner LB, Domachowske JB. Dipylidium caninum mimicking recurrent Enterobius vermicularis (pinworm) infection. Clin Pediatr (Phila). 2008;47(4):397-9.

33. Hoberg EP. Phylogeny of Taenia: species definitions and origins of human parasites. Parasitol Int. 2006;55(Suppl):S23-30.

34. Romig T, Deplazes P, Jenkins D, Giraudoux P, Massolo A, Craig PS, Wassermann M, Takahashi K, de la Rue M. Ecology and life cycle patterns of Echinococcus species. Adv Parasitol. 2017;95:213-314.

35. Laranjo-Gonzalez M, Devleesschauwer B, Trevisan C, Allepuz A, Sotiraki S, Abraham A, Afonso MB, Blocher J, Cardoso L, Correia da Costa JM, Dorny P, Gabriel S, Gomes J, Gomez-Morales MA, Jokelainen P, Kaminski M, Krt B, Magnussen P, Robertson LJ, Schmidt V, Schmutzhard E, GSA S, Soba B, Stensvold CR, Staric J, Troell K, Rataj AV, Vieira-Pinto M, Vilhena M, Wardrop NA, Winkler AS, Dermauw V. Epidemiology of taeniosis/cysticercosis in Europe, a systematic review: Western Europe. Parasit Vectors. 2017:10(1):349.

36. Moro P, Schantz PM. Echinococcosis: a review. Int J Infect Dis. 2009;13(2):125-33.

37. Hao L, Yang A, Yuan D, Guo L, Hou W, Mo Q, Lu Z, Nie C. Detection of Echinococcus multilocularis in domestic dogs of Shiqu County in the summer herding. Parasitol Res. 2018;117(6):1965-8.

38. Boufana B, Qiu J, Chen X, Budke CM, Campos-Ponce M, Craig PS. First report of Echinococcus shiquicus in dogs from eastern Qinghai-Tibet plateau region. China Acta Trop. 2013;127(1):21-4.

39. Yanagida T, Lavikainen A, Hoberg EP, Konyaev S, Ito A, Sato MO, Zaikov VA, Beckmen K, Nakao M. Specific status of Echinococcus canadensis (Cestoda: Taeniidae) inferred from nuclear and mitochondrial gene sequences. Int J Parasitol. 2017:47(14):971-9.

40. Zheng Y. High-throughput identification of miRNAs of Taenia ovis, a cestode threatening sheep industry. Infect Genet Evol. 2017;51:98-100.

41. Shamsaddini S, Mohammadi MA, Mirbadie SR, Rostami S, Dehghani M, Sadeghi B, Harandi MF. A conventional PCR for differentiating common taeniid species of dogs based on in silico microsatellite analysis. Rev Inst Med Trop Sao Paulo. 2017;59.

\section{Publisher's Note}

Springer Nature remains neutral with regard to jurisdictional claims in published maps and institutional affiliations.

Ready to submit your research? Choose BMC and benefit from:

- fast, convenient online submission

- thorough peer review by experienced researchers in your field

- rapid publication on acceptance

- support for research data, including large and complex data types

- gold Open Access which fosters wider collaboration and increased citations

- maximum visibility for your research: over $100 \mathrm{M}$ website views per year

At $\mathrm{BMC}$, research is always in progress.

Learn more biomedcentral.com/submissions 